\title{
SUSCEPTIBILIDADE DE Passiflora nitida AO Passion fruit woodiness virus
}

\author{
MICHEL C. MORAES ${ }^{1}$, MARIA LÚCIA C. VIEIRA ${ }^{1}$, QUELMO S. NOVAES ${ }^{2}$ \& JORGE A.M. REZENDE ${ }^{2}$ \\ 'Departamento de Genética, ESALQ/USP, 13418-900 Piracicaba, SP; ${ }^{2}$ Departamento de Entomologia, Fitopatologia e \\ Zoologia Agrícola, ESALQ/USP, 13418-900 Piracicaba, SP
}

(Aceito para publicação em 10/01/2002)

Autor para correspondência: Maria Lúcia C. Vieira

\section{ABSTRACT \\ Susceptibility of Passiflora nitida to Passion fruit woodiness virus}

Serological and electron microscopy assays confirmed the presence of Passion fruit woodiness virus (PWV) infecting
Passiflora nitida in experimental field in the State of São Paulo, Brazil.
O maracujá-suspiro (Passiflora nitida Kunth), também conhecido como maracujá-de-rato, é uma espécie comestível originária da flora Amazônica; pertence ao sub-gênero Passiflora série Laurifoliae. Trata-se de uma espécie rústica, cujos frutos apresentam sabor exótico e são bastante apreciados para consumo in natura, especialmente na região Amazônica. Além disso, tem sido apontada como resistente a Xanthomonas campestris pv. passiflorae (Pereira) Dye (Menezes, J.M.T. Dissertação de Mestrado. FCAV, UNESP, 1990). Um acesso desta espécie proveniente de Manaus, AM, encontra-se em estudo no Departamento de Genética da ESALQ/USP, visando a caracterização e quantificação da variabilidade genética, onde um total de 120 mudas foram plantadas no campo em 23/02/2000 (Piracicaba, SP). Junto a esta espécie, foram cultivadas 76 plantas de maracujazeiro amarelo ( $P$. edulis $\mathrm{f}$. flavicarpa Deg.). Durante as avaliações visuais das plantas no campo foram observados sintomas semelhantes aos causados por vírus caracterizados por mosaico foliar, amarelecimento entre as nervuras, rugosidade e encarquilhamento das folhas (Figura 1A) e redução no crescimento das plantas. Os frutos apresentavam-se menores, deformados e com manchas corticosas de formato irregular que, em alguns casos, se estendiam por toda a sua superfície (Figura 1B). Manchas corticosas têm sido observadas em frutos de maracujazeiro amarelo no estado de São Paulo. Embora estas manchas possam ser confundidas com danos causados por ácaros, no caso do maracujá amarelo têm sido observadas somente em frutos provenientes de plantas infetadas com o Passion fruit woodiness virus (PWV), gênero Potyvirus, família Potyviridade. Exames ao microscópio eletrônico de transmissão de extratos de folhas de algumas plantas de $P$. nitida revelaram a presença de partículas alongadas, flexuosas, de aproximadamente 10-12 nm x 700-800 nm, típicas do gênero Potyvirus. Amostras coletadas das plantas existentes no campo para diagnose complementar foram submetidas a teste sorológico do tipo PTA-ELISA (Mowat \& Dawson, Journal of Virological Methods. 15: 233-247. 1987), utilizando antisoro contra o PWV e os respectivos controles positivos e negativos. Todas as amostras testadas reagiram com o antisoro, constituindo este o primeiro relato da ocorrência do PWV infetando $P$. nitida, o que evidencia a necessidade de investigação visando o seu controle, caso essa espécie venha a ser explorada para fins comerciais.

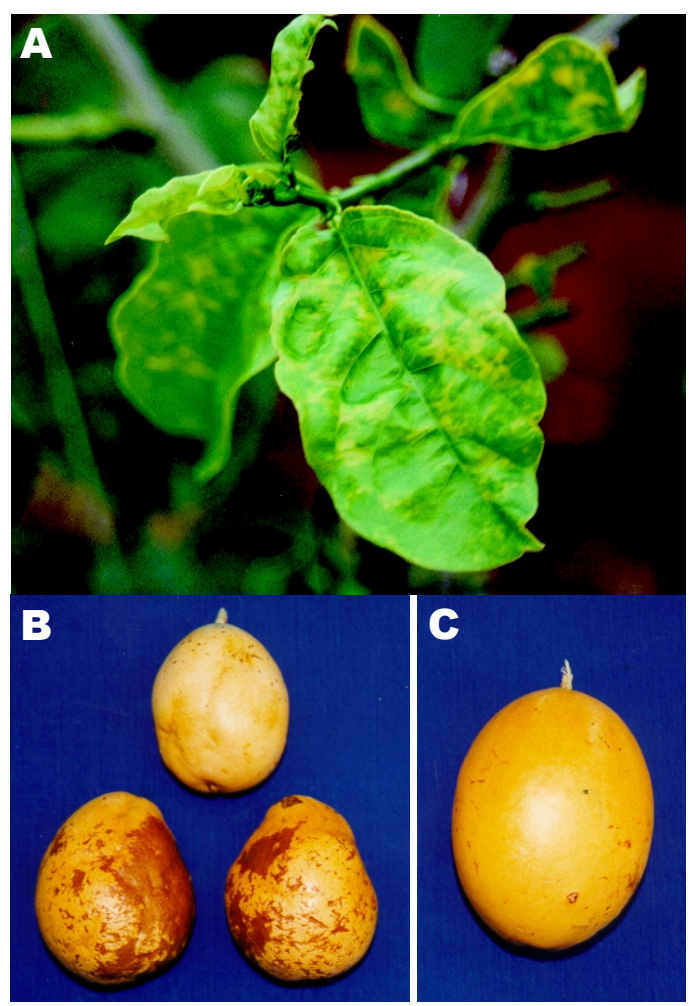

FIG. 1 - Sintomas do Passion fruit woodiness virus em Passiflora nitida. Mosaico foliar (A), frutos colhidos de plantas infetadas (B) e fruto de planta sadia (C). 